\title{
Bureaucratic versus Non-bureaucratic Organization: Explaining Form, Function, and Change in New Forms of Organizing
}

\author{
Iva Petkova ${ }^{1, *}$ \\ ${ }^{1}$ Department of Sociology, Davidson College, Davidson, NC 28035-7011, USA \\ *Correspondence: Department of Sociology, Davidson College, Box 1708, Davidson, NC 28035-7011, USA. \\ Tel: 1-646-823-2595. E-mail: ivpetkova@davidson.edu
}

Received: September 10, 2014

Accepted: September 28, $2014 \quad$ Online Published: October 13, 2014

doi:10.5430/mos.v2n1p33

URL: http://dx.doi.org/10.5430/mos.v2n1p33

\begin{abstract}
This paper reviews recent empirical accounts on the emergence of post-bureaucratic patterns of organizing and examines these contributions against established theory on organizations. The paper reports that while the distinctive features of Weber's bureaucratic type remain unaffected, two trends in contemporary organizing warrant examining convergence in motivation. First, large multidivisional organizations have adopted mutation practices in which the functional structure is overlaid at the level of semi-autonomous project and network organizations. Second, project-based organizations and variants of network forms of organization offer alternatives to the Weberian type by attracting executives to new organizational motivations. The paper defines three conditions for evaluating future novelty claims on post-bureaucratic organizations depending on the variations in two types of motivations for change knowledge transfer and learning. These conditions are related to 1) identifying the exact organizational configurations through which the multidivisional enterprise is mutating; 2) linking change to motivations different from Weberian intentionality and transaction costs economizing logic; and, 3) theorizing new organizational transformations as impermanent organizational entities in which instability is a defining characteristic of adaptation though learning.
\end{abstract}

Keywords: new organizational forms; organizational change; learning; networks; projects; teams

\section{Introduction}

How do we know "what is really new under the sun" in organizations today (Heydebrand, 1989, p. 333)? What observed organizational features constitute "the wave of the future" (Gomes-Casseres, 1994, p. 62)? We know from economic sociology and organization studies that "every evolutionary economic problem requires a social institution to solve it" (Shotter, 2008, p. 2) and that without precedence the social structures offering solutions are organizational structures (Davis and Marquis, 2005, p. 334). Reported by Clegg and Hardy in 1996, the themes of interest concerning organizational research today are three: "What are the different kinds of organizational forms?", "How do these forms arise?", and "How do these forms work?"

Theorizing about novelty in organizational forms has been a problematic effort. Abundant evidence has been produced on the "profound changes [are] occurring in the postindustrial environment and that new organizational forms [are] emerging within it" (Heydebrand, 1989, p. 348; cf. Bell, 1976; Drucker, 1993). A large body of evidence for a changing ontology of economic organization has been produced in which the growing significance of organizational change and adaptation cannot be overestimated to contemporary organization. Changes in the environment and context of organizations are very rapid. New organizational forms appear to be frequently bricolaged (Carruthers \& Uzzi, 2000) and global manufacturers are continually "forced into some form of globalization, disaggregation or structural shift" (Quinn, 1992, p. 55; see also, Dunning, 1995; Feenstra, 1998).

This documented lack of "talking and theorizing about new form of organization" (Powell, 2001, p. 36) has caused divide between theory and practice. Empirical tests to Schumpeter's (1939) hypothesis of linking new resource combinations to novel forms of organization tend to deal with technological innovation (see, Dosi, 1989) and few studies have focused on the emergence of post-industrial routines (cf. Nelson \& Winter, 1982). In the absence of new organizing paradigms defining the impact of organizational environments on the emergence of new forms (see, Stinchcombe, 1965), the business of tracking the emergence of forms, industries and organizations has become "among the most fundamental, difficult, and under-addressed issues in the field" (Chiles et. al., 2004, p. 501; Aldrich 
and Ruef, 2006).

This divide is popularly bridged by practitioner-oriented papers (Walsh et. al., 2006). Only 10\% of all articles submitted between 1991 and 2001 in Administrative Science Quarterly, for example, have followed a theoretical theme, such as, population ecology. All other work was considered to be "broadly topical and ... theoretically eclectic" (David and Marquis, 2005, p. 334). New categories, such as "Networks, learning, embeddedness, trust, knowledge, management and cognition" (Walsh et. el., 2006, p. 658) were proposed to make sense of new forms of organizing. These keyword descriptors broadcast that research today elects to witness organizations by increasing reliance on what is out there in the world.

Are these theorizations different from novelty theorizing offered in the past? With activities being simultaneously legally consolidated and geographically dispersed on a global scale (Bartlett and Ghoshal, 2002), submissions find it is difficult to filter out newness from variations on a theme. The consequence is undertaking ideal type analysis on evidence from partial cases in established organizations. Submissions use various labels to appeal to the diverse palates of academic and professional audiences. Examples that serve as a basis for extrapolations on novelty include large and established firms, as ABB, GE, Seiko, British Airways, J\&J, HP, or Toyota. Proposed new categories include the boundaryless company (cf. Hischhorn \& Gilmore, 1992; Ashkenas, et. al., 2002), virtual corporation (Davidow \& Malone, 1992), network organization (Miles \& Snow, 1995), chaotic form (Smith \& Zeithaml, 1996), disaggregated design (Day \& Wendler, 1998), and more recently, web (Hagel, 2002), and continually morphing online ventures, such as Yahoo!, Excite, (Rindova and Kotha, 2001) or Wikipedia (Puranam et. al., 2014).

Criticism has surfaced in the literature for some of the proposed categories suggesting that the majority of studies on the emergence of new forms show "transformations within the prevalent M-form and are not specifically concerned with the emergence of new forms" (Lewin and Volberda, 1999, p. 520). Heckscher (1994, p. 17) has criticized empirical studies to show "(largely partial and short-lived) examples of organizations that seem deliberately to violate bureaucratic principles". Child and McGrath (2001, p. 1139) have argued that categories generated from individual studies cultivate readers to look for newness at any organization where "both efficiency and innovation, both global operating control and local responsiveness, both centralized vision and decentralized control" occur. Ilinitch et. al. (1996) conclude that the focus on administering organizational advantages leaves theory unaccustomed to discover historical alternatives to Weberian bureaucracy. The implication is that unlike the widespread adoption of Weberian enterprise, the individual cases of organizational change have advanced the existence of dissimilar capabilities that are unsustainable for wide adoption by firms across global industries.

These criticisms indicate that attempts to write up a blueprint based on real-world mix of features may be premature. Weber's (1968) bureaucracy spells out the characteristically modern trend for rationalization of capitalist relations and exhibits a real-world pattern of organizing that overpowers preceding forms. Chandler's (1962) multidivisional firm is an expression of the Weberian hypothesis. It was designed to appeal to managers in large conglomerates in the 1960s, where the form was quickly adopted.

Critics of this perspective caution that Weber's (1968) bureaucracy is not an actual representation, but a "convincing demonstration" (Hecksher, 1994, p. 27) that the development of social organization happens in evolutionary stages. Dunford et. al. (2007) have recently documented that organizational changes in the top 2,011 Australian firms related to proxies such as adoption of new organizational practices indicated "lack of evidence for systemic transformation" (2007, p. 220) and that the adoption of new practices was sometimes associated with greater use of formalized rules and did not result in lower levels of centralization.

I investigate the problem of novelty by proposing that empirical findings about new organizational forms should align with theorizing about post-bureaucratic forms. To illustrate how this may be done, in the next section, I contrast the predictions of 'futurology' organizational scholars (Toffler, 1970; Ouchi, 1980; Mintzberg, 1983; Heydebrand, 1989) with new explanations for the motivations behind organizational novelty in contemporary organizations. A framework is proposed organizing the defining characteristics of novelty in contemporary organizations with motivations for sources of competitive advantage different from those observed in bureaucratic forms of organization. I then take an extensive look at the proposed collections of new practice documented in contemporary multidivisional organizations and new practice observed in variants of project-based organizations and network forms of organization.

The review suggests that inter-organizational networks and project-based forms have become associated with new motivations taking advantage of contextual opportunities in lateral learning. New patterns of organizing are distinct from the bureaucratic type in their collective identities, impact on learning, and documented ability of managers to intentionally examine shifts in motivations and goals (see, Romanelli \& Fiol, 2012; Wry, Lounsbury \& Glynn, 2011). The paper concludes with three conditions for evaluating novelty by future inductive research on new organizational forms. 


\section{What Are Post-Weberian Organizations?}

\subsection{Futurology and Organizational Novelty}

One of the first exercises in reimagining organizational novelty after Weber was offered by Toffler, who argued that "we are witnessing not the triumph, but the breakdown of bureaucracy" (1970, p. 113). Writing roughly twenty-five years before Feenstra (1998) and Dunning (1995), Toffler suggested that bureaucracy is linked to the stage of socioeconomic development in the global economy and that accelerating rates of organizational change are indicative of a shift in the political economy in question. Twenty-five years before James March (1995), Toffler distinguished novelty in the intended organizational design of a 'disposable' organization.

This variant of disposable organization is theoretically charged with the ability to change internal shape with tremendous frequency in which "vast organizational structures are taken apart, bolted together again in new forms, then rearranged again. Departments and divisions spring up overnight only to vanish in another and yet another reorganization" (1970, p. 116). The massive rate of turnover is sustained internally by the assemblage of problem-solving teams from diverse functional departments. These teams are the core of Toffler's post-bureaucratic type. Toffler argued that "teams do not necessarily replace permanent functional structures, but they change them beyond recognition, draining them both of people and power" (1970, p. 121, emphasis added). Toffler insisted that from team-driven transformation does not indicate that an organization will achieve stability. In fact, "the more rapidly the environment changes, the shorter the life span of organizational forms" (ibid, p. 122). Perched against Weber's bureaucracy, Toffler's framework proposes that ad-hoc teams are the solution to high levels of centralization and formalization - the hallmarks of bureaucratic organization.

While Toffler (1970) dealt with the structural features of new forms, strategy scholars turned their attention to understanding the role of knowledge within firms in the 1970s, when Selznick and Nonet (1978) and Ouchi (1980) proposed that the purpose of an organizational form can change from fixed to flexible due to processes associated with generation of knowledge (Table 1). Processes and motivation for learning in flexible organizations require active avoidance of codified routine. The rapid acquisition and production of knowledge in flexible organizations would be sustained by low levels of formalization and centralization.

Ouchi (1980) added to the flexible organization hypothesis by asserting that contemporary (bureaucratic) organizations frequently suffer from incongruence of goals, also called 'double agency', and this can be overcome by erecting "clan" units within organizations. Ouchi grounded his observations in Japanese companies, but theorized that the "clan" practice can be transplanted and thrive in other contexts, as US multinationals. Ouchi and Jaeger (1978) found that clans exist in technologically advanced industries, where teamwork was common, technologies changed often, and individual performance was highly ambiguous. Clans are characterized by common beliefs "that individual interest is best served by a complete immersion of each individual in the interests of the whole" (1980, p. 136).

Whereas the location and commercial performance of clans in Ouchi's (1980) analysis is not as important as their purpose of organic solidarity, clans are established and located in predominantly large multinationals. Ouchi and Jaeger (1979) proposed that a unique characteristic of learning through $Z$ teams in established organizations is that their motivation for existence does not require evaluation. Because of their orientation to learning, $Z$ teams are capable to promote organic identification with a collective and this Durkheimian vision eventually splits the confines of bureaucracy in which these teams operate. The Ouchian $Z$ theory is an important theoretical construct moderating the effect of turmoil in organizations that continually adapt to ambiguous performance criteria in rapidly changing environments.

During the 1980s, Mintzberg (1983) and Heydebrand (1989) provided additional typologies of post-Weberian organization. Mintzberg (1983) classified five ideal organizational types. His 'simple structure' was characterized by explicit and fixed jurisdiction. 'Machine bureaucracy' was similar to Weber's (1968) and Burns and Stalker's (1961) concepts. The multidivisional form (MDF) is another bureaucratic variant. Mintzberg explained it as a "quasi-autonomous structure coupled together by a central administrative structure" (Mintzberg, 1983, p. 215). Importantly, Mintzberg argued that M-forms emerge not from decentralization of machine bureaucracy, but from centralization of independent organizations. This is why he predicted that increasing levels of centralization will be observed in large Chandlerian corporations, despite the quasi-independence organic internal units, as Z-clans, may enjoy. Mintzberg predicted that increasing centralization will result in the complete fragmentation of the M-form. Mintzberg's final form is similar to Toffler's "adhocracy". In Mintzberg's adhocracy, novelty emerges in "multidisciplinary teams, each formed around a specific project of innovation" (Mintzberg, 1983, p. 256) continually recombine existing knowledge and skills. 
Heydebrand (1989) criticized Mintzberg's (1983) typology and proposed that the current multidivisional organization exhibits properties that are far more complex internally than the divisional form described by Mintzberg five years earlier. The advent of new technological systems helped managers to "undermine older social and technical forms of control" (Heydebrand, 1989, p. 342) and this trend would lead to the emergence of loosely coupled profit centers with decentralized decision-making in the future.

Heydebrand (1989) did not conceptualize the M-form as the finale in organizational development. He argued that contextual processes related to increasing technological capability in some contexts, such as electronics and aerospace, will cause decline in the Weberian type by improving social rationalization of management processes and laying foundations for a new organizational culture and practice. Heydebrand's (1989) social rationalization process examines managerial intentionality as a prime factor of importance in the reengineering of the M-form. Post-Weberian forms that will follow the M-form will "amount to a shift in the mode of administration, if not production, rather than a monolithic continuation [...] in Weber's master trend of rationalization" (1989, p. 339, emphasis added). Heydebrand (1989) agreed with Ouchi's prediction for participatory learning of new units and argued that new forms would be decentralized, participative and fluid; their size will be small; or, that they may be "small subunits in larger organizations" (Heydebrand, 1989, p. 337).

Table 1. Bureaucratic Mutations, and Post-Bureaucratic Impermanent Forms

\begin{tabular}{|c|c|c|c|c|}
\hline Features & Bureaucratic & Mutations & Post-Bureaucratic & Impermanent \\
\hline Form & $\begin{array}{l}\text { Simple; Machine } \\
\text { bureaucracy } \\
\text { (Mintzberg, } \\
\text { 1983). }\end{array}$ & $\begin{array}{l}\text { M-form mutations } \\
\text { Z-Clans (Ouchi, } \\
\text { 1980); M-form } \\
\text { (Heydebrand, } \\
\text { 1989). }\end{array}$ & $\begin{array}{l}\text { Organic (Burns } \\
\text { and Stalker, 1961); } \\
\text { Adhocracy } \\
\text { (Mintzberg, 1983); } \\
\text { N-form (Hedlund, } \\
\text { 1994); Flexible } \\
\text { (Selznick \& Nonet, } \\
\text { 1978). }\end{array}$ & $\begin{array}{l}\text { Adhocracy (Toffler, } \\
\text { 1970); Chaotic } \\
\text { (Volberda, 1996); } \\
\text { Ambidextrous } \\
\text { (Tushman and } \\
\text { O'Reilly, 2006); } \\
\text { Disposable } \\
\text { (Toffler, 1970). }\end{array}$ \\
\hline Purpose & \multicolumn{2}{|c|}{$\begin{array}{l}\text { Articulated systems of knowledge. } \\
\text { Assumption of stable social and } \\
\text { economic environment (Selznick \& } \\
\text { Nonet, 1978) } \\
\text { Explicit; fixed (Selznick \& Nonet, 1978) } \\
\text { Vision dictated (Child and McGrath, } \\
\text { 2001) }\end{array}$} & \multicolumn{2}{|c|}{$\begin{array}{l}\text { Emergent systems of knowledge } \\
\text { (Volberda, 1996). } \\
\text { Assumption of shifting environment } \\
\text { (Selznick \& Nonet, 1978); } \\
\text { Blending processes (Hannan and } \\
\text { Freeman, 1986) } \\
\text { Mission-oriented (Selznick \& Nonet, } \\
\text { 1978) } \\
\text { Vision emergent (Child and McGrath, } \\
\text { 2001) }\end{array}$} \\
\hline $\begin{array}{l}\text { Centralization/P } \\
\text { ower }\end{array}$ & \multicolumn{2}{|c|}{ Concentrated (Weber, 1968) } & \multicolumn{2}{|c|}{$\begin{array}{l}\text { Diffused, distributed, substantive } \\
\text { (Selznick \& Nonet, 1978) }\end{array}$} \\
\hline $\begin{array}{l}\text { Formalization } / \mathrm{R} \\
\text { outines }\end{array}$ & \multicolumn{2}{|c|}{$\begin{array}{l}\text { Codified; Blueprints for action (Selznick } \\
\& \text { Nonet, 1978) }\end{array}$} & \multicolumn{2}{|c|}{$\begin{array}{l}\text { Subordinated to purpose (Selznick \& } \\
\text { Nonet, 1978) } \\
\text { Active avoidance of routine (Ouchi, 1980) } \\
\text { Tacit knowledge (Hedlund, 1994) } \\
\text { Participative management logics, } \\
\text { co-evolution (Lewin and Volberda, } \\
\text { 1999). }\end{array}$} \\
\hline Size/Lifespan & \multicolumn{2}{|c|}{$\begin{array}{l}\text { Large tiered units. } \\
\text { Stability/longer lifespan. }\end{array}$} & \multicolumn{2}{|c|}{$\begin{array}{l}\text { Smaller co-participative units (Hedlund, } \\
\text { 1994). } \\
\text { Impermanent Teams (Toffler, 1970). } \\
\text { Unpredictability/shorter lifespan. }\end{array}$} \\
\hline $\begin{array}{l}\text { Level of } \\
\text { analysis }\end{array}$ & \multicolumn{2}{|c|}{$\begin{array}{l}\text { Firm, population, industry, audience. } \\
\text { (Williamson, 1991; Cyert and March, } \\
\text { 1963; Burns and Stalker, 1961; Nelson } \\
\text { and Winter, 1982; Teece et. al., 1997; } \\
\text { Kogut and Zander, 1992). }\end{array}$} & \multicolumn{2}{|c|}{$\begin{array}{l}\text { Interorganizational units, teams, meso } \\
\text { level of analysis. }\end{array}$} \\
\hline
\end{tabular}




\section{New Explanations of Non-bureaucratic Organizations}

\section{(a) Capturing Emergent Knowledge}

The directionality of research on new organizations has headed increasingly in the direction of explaining the emergence of novel purpose with the production of new knowledge. Boisot and Child (1988) and Hedlund (1994) have argued that knowledge originates within small groups of learners or in interorganizational units, because at these levels "articulated knowledge becomes tacit" (1994, p. 76-77). In conventional Weberian hierarchy, small groups of learners are unsupported formally to expose the organization to tacit knowledge, because bureaucracies are fit to reap returns from formalized, articulated and rule-bounded systems of knowledge. Hedlund (1994) argued that novel knowledge-intensive organizations (or, N-forms) can be part of a larger "multifunctional, multinational, multidivisional" organization (ibid, p. 84), but these units would be able to develop and possess knowledge that differs from the types of knowledge supported in the M-form by supporting recombination of capabilities and the sharing of tacit knowledge. Similar idea of a novel 'flexible' form was proposed in 1996 by Volberda, who argued that in the turbulent institutional environments of today management needs "extensive, multidimensional collection of capabilities" (p. 362) that mixes close-knit and even formalized communication with tacit intra-firm relations.

The $\mathrm{N}$-form and the flexible form are driven by assumptions, other than economic performance and their motivation is emergent. In capturing the purpose of knowledge, the two forms make extensive use of projects, teams and alliances; their structure is disembedded from formal assets and their unit size is small. The $\mathrm{N}$-form and the flexible form grow through knowledge supported by disposable Tofflerian teams. When knowledge accumulation reaches a certain limit, $\mathrm{N}$-forms can mutate into 'chaotic' forms, the final form on Volberda's (1996) continuum. Volberda's chaotic form reminds of Toffler's (1970) adhocracy and is a very unstable" kaleidoscope of shifting coalitions, chaotic communication patterns, random combinations, and general information overload" (Hedlund, 1994, p. 85).

\section{(b) Management Intentionality}

Managerial intentionality is another important factor delineating the boundaries of new forms in recent organizational research. Nonet and Selznik predicted in 1978 that forms arise "out of the character of the social system under construction" (1978, p. 21). New organizational submissions have discussed that research in organizational novelty should support levels of analysis that are both supra-firm and at the level of teams, or sub-firm. This analytical framework merges the macro analysis of organizations with a meso approach to explaining processes by which learning facilitates emergent, purpose-related outcomes for organizations.

Brown et. al. (1996) have argued that contemporary organization research has documented that organizations shape and respond to their socio-cultural contexts. Child and McGrath (2001) and Davis and Marquis (2005) have predicted that the relationship between organizations and their organizational contexts facilitates the emergence of newness. Lewin and Volberda (1999) have proposed that the relationship between organization and context is one of co-evolution of classical forms, including Weber's (1968) bureaucratic form and Chandler's (1962) M-form, with contextual upheavals of the industrial age. Lewin and Volberda (1999) suggest that change in organizational forms occurs at the gap between managerial intent and organizational context and "need not be an outcome of either managerial adaptation or environmental selection" (ibid, p. 526).

One example detailing the potential for utilizing managerial intentionality as a proxy for defining the boundaries of new forms is the conceptual evolution of population ecology. In 1986, Hannan and Freeman proposed that the key to distinguishing forms within populations is to focus on two processes between populations of firms: blending and segregating. Segregating processes were considered to be activities related to the codification of the form and were related to the adoption of institutionalized routines by actors. Blending processes reflected the struggle to make sense of contextual upheavals in the 1980s and would occur during times of "deinstitutionalization, perestroika, or reorganization" (Heydebrand, 1989, p. 332). Hannan and Freeman (1986) linked blending processes to "conscious revision of forms and routines" (1986, p. 63, own emphasis). The founders of population ecology indicated with this particular hypothesis that organizations can emerge along trajectories of management intentionality in order to take advantage of contextual opportunities.

After 2000, submissions in population ecology redefined form as the 'meaning' imparted for actors in a domain, but distinction among forms became dependent on the degree of their institutionalization (Hannan et. al., 2002; Hannan, 2005; Hsu and Hannan, 2005). This level of analysis de-emphasized managerial intentionality as a factor of importance to the emergence of new principle, purpose, and goals in organizations. Focusing on institutionalization during times of tremendous change in organizational environments enables research to look for established forms because ecology proponents argue that "firms routinely change their architectures without changing their identities" 
(Carroll and Hannan, 2000, p. 64) and forms "do not exist independent of external agents" (McKendrik et. al., 2003, p. 6).

New studies on organizational emergence propose that new forms are 'co-evolutionary'. They evolve along with the organizational environment in which an organization is embedded at the same time as executives shape new practices and culture on-the-go by looking at the institutional environment in which their organization is embedded (see, Koza and Lewin, 1998). Dijksterhuis et. al. (1999) have operationalized some of these co-evolutionary variables by suggesting that 'management logics' (sets of context-specific macrolevel beliefs that influence what managers do) are employed as an independent intervening variable in the co-evolution process between form and context.

Co-evolutionary studies focus on the procedural aspects of co-evolution between populations and their environments (cf. Koza and Lewin, 1998; Galunic and Eisenhardt, 1996). Even though few submissions here adopt a microsociological approach to look at the mechanisms of evolution of emergent new purpose, beliefs and identity, co-evolutionary studies reinstate Weick's (1977) submission that organizational members socially enact their environment. They facilitate the adoption of an organizational sociology approach to the study of knowledge creation and the content of novelty.

\section{From M-Form to Adhocracy: Mutations in the Multidivisional Form}

The connection between transformations in the M-form and the emergence of novelty has been suggested to tantamount in organization research to "the shift that occurred among large corporations in the 1950s, 1960s and 1970s from functional governance structures to multidivisional structures" (Zenger and Hesterly, 1997, p. 216). Palmer et. al.'s (2007) two-stage analysis of organization literature between 1992 and 2005 presents a case in point. The authors found that organization research in established forms during that decade has focused on eight recurring practices: "networks and alliances, outsourcing of non-core activities, disaggregation of business units, de-layering, reduced internal and external boundaries, flexible work groups, empowerment and short-term staffing" (2007, p. 1841). In the large scope of single case-studies, three practices among these, downsizing, delayering and devolving, have been reported as new phenomena in corporate governance (cf. Nohria and Eccles, 1992; Powell, 1990). In empirical cases where all three practices occur, researchers have proposed that the result is a new form(Note 1).

Accounts of transformation in the $\mathrm{M}$-form begin with suggesting that there is a growing experiment with delayering initiatives contributing in the general to decline in the size of large firms. Zenger and Hesterly (1997) have reported that the distribution of employment by firm size in the US for companies from all sectors with more than 10,000 employees has decreased from $25.6 \%$ in 1963 to $19.3 \%$ in 1987. Statistics are rare on the prevalence of downsizing and on linking downsizing with new governance mechanisms and acquisition of knowledge. Anecdotal evidence has linked delayering initiatives, as outsourcing, to labor arbitrage, because "without doubt, big layoffs often accompany big outsourcing deals" (Engardio, 2006). Criticism has emerged asserting that internal restructuring in large organizations is a "false" premise on which to proclaim novelty (Heckscher, 1994, p. 29).

More generally, management scholars have argued that the benefits of vertical integration have diminished to firms, because time horizons have shortened (Quinn, 1992). The literature has explained delayering initiatives as examples of "externalization: disposing of internal units and contracting out functions formerly performed in-house" (Scott, 2004, p. 11, own emphasis). Design and cost pressures expose firms to risks associated with non-performing in-house functions and slashing costs has the advantage of producing more compact organizations. Whereas some authors have claimed that when internal restructuring and outsourcing are combined, the result is the emergence of "intelligent enterprises" (Quinn, 1992), more generally, delayering is linked to profit. Quinn (1992, p. 57) proposed that Sony and Matsushita decommodified their competences by absorbing film and distribution companies "to keep afloat margins and revenues". Afuah (2001) has noted that when previously non-networked firms integrate vertically into an emerging new technology, they will experience superior performance(Note 2)

These opinions offer another layer of normativity in the debate on novelty. In most of the reported cases disaggregation related to reducing (or inflating) the size of large firms by acquisition and slashing down of functions is not related to more collective experiment. In fact, reorganizations in the existing $\mathrm{M}$-form, including results from outsourcing of "non-critical" functions, have been linked to the emergence of new, 'modular' forms of organization in which decision-making processes remain relatively centralized (Dess et. al., 1995; Lei et. al., 1996; Schilling \& Steensma, 2001). Modular forms offer a variation on the multidivisional firm. Malnight (2001) compared the evolution in management practices of Lilly and Roche during a fifteen year period (1980-1994) and suggested that increasing complexity in their internal structures was joined by convergence in their processes. Pharmaceutical firms engage in 
similar core activities at the stages of discovery and regulatory approval, but present a special case of organizational arrangement, because there are decentralized processes related to local operating authority and standards. This makes big pharmaceuticals loosely federated and highly centralized in core aspects of their value chains(Note 3). Malnight (2001) uses this special case to establish the emergence of new goals in pharmaceutical firms, even though the cross-functional task forces used to manage discovery operations in both firms use highly routinized processes of decision-making.

Examples from other industries using this normative approach to defining novelty in M-forms are large accounting firms. Brown et. al. (1996) have argued that these players follow clients by establishing "loose strategic alliance of quasi-autonomous firms" (1996, p. 65) in which operating control is decentralized and the use of rules and procedures is low. This federated structure was abandoned in the 1990s, when clients were prompted by regulations to require more general business advice. Brown et. al. (1996) have called the new configuration a new "professional managerial hierarchy" form. The "hierarchy" operates on the basis of joint decision-making by all previously quasi-independent national firms. Even though the form employs executive committees and cross-functional teams, in this transformation the use of formal rules and procedures is high and decision-making shifts from joint to directive.

The examples show that reconstruction of control mechanisms in some large organizations is likely to preserve the Weberian logic along which contemporary bureaucracies are organized and more conservative gauges on novelty are necessary. The study of lateral initiatives in which teams are prevalent and relatively independent within the larger structures of M-corporations has been one suggestion. Anecdotal evidence links lateral initiatives involving teams with transformational effects to organizations (Verespej, 1990; Gordon, 1992; Mehta, 1994). Organizational researchers have had difficulty documenting the propensity by large and medium organizations to adopt lateral governance mechanisms. The consensus is that the trend is "gradual in most firms, dramatic in some, and nonexistent (or nearly so) in others" (Fulk \& Desanctis, 1995, p. 338).

Fulk and Desanctis (1995) have proposed that delayering amounts to a new form only when existing hierarchy can yield to lateral linkages promoted between teams in the functional structure, including the linkages facilitated by new digital technologies. Birkinshaw and Hagström (2000) have argued that more rigorous measurement is necessary because lateral organizing frequently leads to problems of double agency at those levels in the organization where new lateral units convene with functional arrangements (also, see, Child and Rodrigues, 2003). Palmer et. al. (2007) have asserted that to constitute novelty, lateral arrangements in large firms have to be maintained exclusively "without the assistance of traditional bureaucratic hierarchies" (2007, p. 1834, emphasis added).

Comparative accounts on the experiences of 512 employees in 8 diverse organizations with lateral initiatives have concluded that lateral initiatives can be successful only when lateral managers across the sample (e.g., senior unit, program, project or brand) continued relying on the opinions of functional peers (Joyce et. al., 1997). In themselves lateral initiatives were thought to "improve communication, encourage consensus decision-making and require interdepartmental interaction prior to decisions" (Joyce et. al., 1997, p. 13). In this case of M-form transformation across the sample, lateral mangers could not independently "rely on their positional power" (1997, p. 14).

Cross et. al. (2000) have suggested that the problem of double agency can be resolved by the imposition of boundary spanning activities. The transition from functional to a team-based structure in the US National Cooperative Bank (NCB) necessitated that a third transformation- "bringing up boundaries at the work unit level" (2000, p. 845) -was implemented jointly with instilling project logics into a functional enterprise. When the bank transitioned to what authors describe as 'team-like' structure, it auctioned a variety of teams responsible for the development and selling of credit instruments, pulling down formalized control. Teams became independent from the functional structure, but cross-training initiatives involving functional specialists became crucial for the success of the initiative.

Brynjolfsson et. al. (1997) have shown that continuous improvement processes, such as total quality management (TQM) and learning from mistakes "can be counterproductive" to organizations (1996, p. 4). At the medical production firm studied by the authors, the target design of cross-functional teams interfered with existing functional work-groups and tiered management practice. When the existing functional structure remained intact, there was difficulty to produce new knowledge and learn from it.

The examples demonstrated here concur with Toffler's (1970) hypothesis that lateral initiatives accompanying processes of delayering do not remove functional hierarchies, but add non-hierarchical structures to them. Conceptual definitions of restructuring in large corporations (and smaller firms) can systematically be linked to mutation practices espoused by the existing population of organizations. Processes of delayering and renovation in large and medium firms cannot alone derive the emergence of a novel organizational form, because these initiatives do not necessarily 
lead to accumulation of new forms of knowledge, increase the "dialogue among various parts of the organization or create a system of collective experimentation" (see, Heckscher, 1994, p. 29).

\section{Temporary Forms of Organizing}

Temporary forms of organizing are typically associated with project forms of organization (PFOs) (DeFillippi \& Arthur 1998; Hobday, 2000; Whitley, 2006) and knowledge intensive service firms, or KIS (Chiesa et. al., 2004). PFOs and KIS are specialized independent firms that offer services to other firms from "initial concept definition, through design, engineering, prototyping, and laboratory testing, to final commercialization and marketing" (2004, p. 65).

Project forms of organizations can be of two types: 'project-led' organizations, in which large of medium organizations 'host' projects as parts of their operations, and 'project-based' organizations, which are firms structured around project logics of varying temporality (Hobday, 2000). The first time that project-based forms, or PBFs, were conceptualized as a new empirical phenomenon was in 1994, when Hedlund dubbed them as 'totally emergent entities'. The emergent empirical qualities of PBFs make for a challenging case of novelty. In the first special issue on project forms in Organization Studies, Sydow et. al. (2004, p. 1480) noted how the study of this NFO is "rather [...] empirical level of interest than a clearly bounded theoretical subject area". Project-based forms are "temporary" and "impermanent" organizational forms embedded in more permanent organizational contexts and organized around the performance of a project (Sydow et. al., 2004). Projects move along ambiguous performance criteria, and are built conceptually along collaborative experimenting boundaries. Project-based forms are novel forms of organization that combine the properties of Hedlund's (1994) N-form and Volberda's (1996) chaotic form.

PBFs vary in structures and processes that they adopt and the uncertainty they tolerate. Whitley (2006) has suggested to gauge novelty of a PBF by the duration, uniqueness, and singularity of project outputs. In creative or new industries such as film, entertainment, and new media, PBFs turn into Volberda's (1996) chaotic form. They organize around highly singular goals and dissolve upon project completion. It is common that when project goals are singular, the project firm is found only for the duration of the project, for "organizational convenience" (DeFillippi and Arthur, 1998, p. 137). The implication to organizational novelty here is that the knowledge acquired at the level of the project is not retained or absorbed into a larger and more permanent organizational structure.

Lindkvist (2004) proposed another gauge on novelty in PBFs that divorces the form altogether from the confines of functional organization. The proposal is to measure the extent to which structure and process in projects organize around project and not functional dimensions linking novelty to roles and identities around which temporary organization is established. Examples of this analytical approach are Grabher's observations of the Munich enterprise software industry in 2004. Grabher (2004) considers the industry as a new form because roles and outputs were not clearly defined. Whitley (2006) has similarly suggested that project-based organizations that are unique and dissolve with the completion of deliverables are similar to projects based on multiple roles and identities. Highly unique projects tend to begin and end as impermanent structures. In accord with Volberda's (1996) chaotic form, unique PBFs generate the knowledge necessary for the completion of the project, but do not retain it at an organizational level.

Recent evidence suggests that unique PBFs, such as boutique biotechnology firms, may however persevere to a permanent organizational structure. Whitley (2006) has reported that as markets for drugs develop, small biotech firms retain important roles in an ecology around drug development. These PBFs do not dissolve on project completion, and continue to be independent "instead of being swallowed up by established pharmaceutical companies" (Whitley, 2006; cf. Powell et. al., 1996).

Based on the stability of project roles and singularity of project outputs, Whitley (2006) has advanced a further PBF typology scoring differently (high-low) on two proxies. 'Craft' PBFs are found in IT consulting or professional business firms and are characterized by simple goals and stable functional roles. Results from Bresnen et. al. (2005) show that 'craft' PBFs are not associated with acquisition of new knowledge because their organization is most likely to lead to the problem of double agency. The authors examined the dispersion of management practice in four 'craft' PBFs - two engineering firms, one oil company, and a large MNC division. They found that the success of project organizations depends on the preexisting internal structure of organizations engaging with the form. In two examples, attempts to decentralize work arrangements worked against company culture and the project was swallowed up by a double agency problem between functional management and "managers on the sites" (2005, p. 34).

'Precarious' PBFs are Whitley's (2006) most impermanent project organization form. This project form is characterized by Tofflerian levels of instability. Precarious PBFs involve risky and unusual outputs mixed with highly volatile roles and skills. The division of labor is unstable, organizational procedures are informal and the problem of 
double agency is actually an expected result of this arrangement. Precarious PBFs exist in biotech and software start-ups. Precarious PBFs rarely lead to permanent structure because the changeability of goals and the high degree of decentralization of teams can cause problems in the development, diffusion, and maintenance of new organizational routines. Precarious PBFs are also the only unstable form that can continue to exist and aggregate knowledge on the principle of precariousness. Whitley (2006) on reports that some biotechnology firms working on precarious project logic are able to develop permanent structures and continue to operate.

\subsection{Project-led Forms (PLFs)}

Large MNCs and their divisions can also nest PFOs. Because functional structures in multinational firms tend to develop their own 'thought worlds', the hosting of a project form within a functional hierarchy of large organizations presents difficulties for the retaining of independent thought. Sydow et. al. (2004, p. 1478) have argued that it "matters a lot if the project is embedded in functional or a business unit." Depending on the configuration, members will either be let go or be re-absorbed into the organization at the end of the project.

Brady and Davies (2004, p. 1606) have documented that the problem of double agency is typically resolved when large firms experiment with projects that may become key new lines of 'repeatable' business, "such as turnkey, outsourcing, design-build-operate, or public-private partnership (PPP)". During "phase 3" of these projects, the larger firm "hosting" the smaller structure can attempt to consolidate learning by absorbing project cash-cows into the formal structure. In this case, retaining of project units as business or functional units on assumptions of future profit is an indication of absorbing project logics into the functional organization.

Projects are established to get to a common understanding of the "'anatomy' of the intended product" (Engwall and Westling, 2004, p. 1563). When large firms open up their processes to PBFs, there is a momentum for reconfiguring and recombining of new knowledge in large organizations. In subsequent periods, the overarching business goals of large organizations have little tolerance for sustaining impermanent structures. The reason for the reversal to old culture is straightforward. Flexible arrangements should have limited duration to not affect the permanent organizational design.

\subsection{Project Forms and Network Forms of Organizing}

Network forms of organization are the final organizational configuration that can host project based organizations. Although Windeler and Sydow (2001) have noted that "the constitutive mechanism which turns projects into a network form of organization [...] has not been elaborated until now" (2001, p. 13), attempts are made to provide description of project networks. Windeler and Sydow (2001) argue that the de-regulation and privatization of the German broadcasting market fostered novel forms of organization in which content production is carried out collaboratively in project networks. A provider of programming or a broadcaster triggers the process by stimulating a producer to form a project. The authors note that actors enter the project as dyads (e.g., director-producer) and work with rest of the group on temporary project terms.

There is difference between networks of project based organizations working together and the previous example of large firms hosting the project form. In the former case, there is shared understanding that projects are created with limited duration and hosting network organizations can 'play' with the finite timeline by re-selecting new members. Uzzi and Spiro (2005) note in their study of project networks in Broadway musicals that the degree of access of artists to diverse pools of creative material increases when the connectivity and cohesiveness across the project based network is high. In such organizational settings, both the level of formalization and centralization are low and lateral coordination allows knowledge to be shared.

\section{Network Forms of Organization (NFO)}

As mutations of the M-form continued, a different phenomenon, the formation of network forms of organization (NFO), gave rise to new research platforms in the 1990s. In economic sociology, the argument originates in Powell (1990), who "imaginatively explored" (Perrow, 2001, p. 465) that in situations where exchange looks "more like a marriage than a one-night stand, but there is no marriage license" (1990, p. 301), a more socialized exchange emerges. Powell's argument was that in network forms of organization, networks of individuals engage in "reciprocal, preferential and mutually supportive actions" (1990, p. 301) and units exhibit a "go-it-along" approach in relation to other units (Cravens et. al., 2006).

A defining feature of the network form is its saturation with organic solidarity of the Ouchian Z-type. The Japanese connection is not coincidental. Sociological interest in the network form was spurred by scholars interested in 
explaining the prevalence of network forms in Japanese firms (see, Dyer \& Nobeoka, 2000). Lieberman and Asaba (1997) found that the similar technological endowment of US and Japanese enterprises in the area of lean production techniques resulted in greater labor productivity for both automakers and suppliers in Japan, and stagnating productivity in the US. The trend continued until Japanese automakers established facilities in the US in the 1980s and began the process of transplanting knowledge to their subsidiaries. Using Silicon Valley as an example, Bahrami (1992, p. 44) has argued that success in the transfer of knowledge and new cultural identity in organizations is achieved when firms realize that knowledge can be attained not by keeping it inside an organization, but by breaking down "the solid walls which have historically separated the firm from its external stakeholders".

Network forms of organization (NFOs) received their formal definition in Podolny and Page (1998, p. 59) as governance mechanisms (equity and non-equity) in which "any collection of actors $(\mathrm{N}>2)$ pursue repeated, enduring exchange relations with one another and, at the same time, lack a legitimate organizational authority to arbitrate and resolve disputes". Organizations typically associated with this definition are "joint ventures, strategic alliances, business groups, franchises, research consortia, relational contracts, and outsourcing agreements" (1998, p. 59). In themselves, these organizations are not new. It is their novel cultural linkages with one another that suggest the establishing of new purpose and goals.

Research on network forms of organization has grown exponentially since the 1990s, although Fligstein's caution still holds that we know little of how "prevalent and paradigm-breaking network forms of organization really are" (2000, p. 663). Powell (1990) has tangentially related the emergence of network forms to transformations in the M-form. He notes that international joint ventures, large firm-small firm linkages, and subcontracting arrangements are used by large firms after these become vertically disaggregated. Powell's 1990 hypothesis was confirmed by Achrol in 1997, who documented that networks "have risen to prominence due to industrial restructuring" (Achrol, 1997, p. 57) of the M-form. Powell (1990) and Achrol (1997) both echo Heydebrand's (1989) hypothesis that organizational novelty should be identifiable from the stage of economic development.

For Powell (1990), network forms are consistently associated with inimitable advantages in innovation and learning. Writing in 2001 for DiMaggio's The $21^{\text {st }}$ Century Firm, Powell cautions that the search for new organizations may difficult because researchers may find models based on "remnants of existing practices and partial set of new arrangements" (2001, p. 39). Support for network forms as carriers of novelty was given by Carruthers and Uzzi in 2000 , with the argument that participation in inter-organizational networks produces changes in the cultural identities of conventional actors associated with production, distribution and consumption.

Since these seminal submissions, organizational sociology has also linked network forms with superior advantages for embedded firms. Podolny and Page (1998) have argued that network forms create value in two ways: a) by promoting rapid transfer of knowledge between firms, b) by encouraging novel syntheses of information produced by partners with a long-term relation (cf. Granovetter, 1974, Powell, Koput and Smith-Doerr, 1996).

Factors, such as "norm of reciprocity" (Powell, 1990), "embedded ties" (Uzzi, 1997), weak and strong ties, multiple pathways, few structural holes, high centrality, wide geographical scope, experience in managing alliances, and many others are documented or hypothesized to flow through the network and empower actors to generate or share knowledge (see, also, Powell et. al., 1996; Anand \& Khanna, 2000; Dyer and Nobeoka, 2000). These positive effects are thought to produce 'inimitable value-generating resources' for firms (Gulati et. al., 2000) and are gauged by the higher profitability of firms internal to the network and lower profitability of firms that are external (also called 'liability of unconnectedness' in Podolny \& Page, 1998).

Research on organizational networks has suggested a three-stage post-partum 'network formation process' that begins with the vertical disaggregation in the M-form (Miles \& Snow, 1986), followed by internal redesign (Quinn, 1992), and the formation of various alliances (Achrol, 1991). Hirschorn and Gilmore have argued that in this sequential transformation the definition of novelty is the replacement of "vertical hierarchies with horizontal networks; linking together traditional functions through interfunctional teams; and forming strategic alliances with suppliers, customers, and even competitors" (1992, p. 157).

The logic here suggests that after large firms break up, "smaller, more focused, vertically disaggregated firms" (Achrol, 1997) emerge and these organizations, having been established directly because of transformational processes on the other side, are novel forms of organizing. Organizational sociology hypotheses enthusiastically predict that with the breakage of the M-form "the future belongs to quick, constantly learning small firms" (Fligstein, 2000, p. 224) who must enable a set of alliances and networks with large counterparts to maintain fitness (Powell, 2001; Stuart, 1998; Stuart et. al., 1999). 
The challenge of proving that small firms employ novel cultural architectures is methodological. The small firm is not a new organizational arrangement, but the literature suggests that small firms increasingly organize around new cultural logics. Perrow has argued that there is a lack of clarity "from the literature that in all cases networks of small firms are involved" (2001, p. 456, emphasis added). In the US, small firms create around $70 \%$ of new jobs annually, produce 13 to 14 times as many patents, and tend to go global before growing up (US Small Business Administration, 2006). However, as with the lack of systemic evidence for the transformation of the M-form, there is no systematic data of the nearly 25 million small firms suggesting that these forms are networked. Small firms do not have supply chains and they do not outsource at least in the conventional sense. Due to these issues, more evidence is needed from populations of organizations from new or established industries to suggest that small firms are representatives of new organizational logics (Perrow, 2001; cf. Saxenian, 1994; Uzzi, 1997).

\subsection{Exploring Novelty in Network Variants - Joint Ventures and Strategic Alliances}

Strategic alliances are a common example in discussions of network forms case-studies. Learning is a key question of interest in network studies and learning effects are frequently hypothesized to add value to strategic alliances as organizational forms. Two popular variants of network forms are explored in the literature: joint ventures and strategic alliances. Joint ventures can be decoupled from new organizational logics easier. They are a well-known equity mode which "most closely replicates the hierarchical control features of organizations" (Gulati, 1998, p. 300; cf. Andrews, 1971; Pfeffer and Nowak, 1976). Strategic alliances are more complex. They involve loosely coupled governance modes that do not share equity and have few hierarchical controls (Hagedoorn, 1995). The need to learn in rapidly changing consumer markets is the main factor bringing firms together in alliances.

Network forms involving alliances are made up by either large firms perforating emerging horizontal networks of smaller supplier firms (e.g., franchising models, such as Benetton's, or subcontracting models, such as Toyota's); or by linkages between mid-size or large partners that come together for a particular goal, such as "reducing the gap between conception and execution" (Perrow, 2001, p. 459, own emphasis). Castells (1996) has argued that franchising or subcontracting modes are hybrid-like in form and bureaucratic in purpose. Newer practices of longer contracts and mutual problem-solving, especially in the auto-industry, have made the large firm-small subcontractor model attractive in terms of documented cultural advantages from learning to firms (Helper, 1993; Dyer, 1996).

Gulati (1998) has argued that regardless of the equity involved in setting up a network form of governance, firms will develop trust through prior ventures and "progressively use less hierarchical structures in organizing new alliances" (1998, p. 303). Thus, there will be a progression from more hierarchical (joint ventures) to less hierarchical (alliances) variants in firm cooperation and this latter stage will be associated with organizational novelty.

In the majority of cases, alliances are established for tangible reasons and, similarly to project forms, are of a particular temporal span. The MIPS group is one popular example (Gomes-Casseres, 1994). MIPS was established to promote RISC technology (Reduced Transaction Set Computing Technology) between a number of large firms and for a particular duration. Gomes-Casseres (1994) argues that the alliance failed due to problems with the "conceptualization" of technology. Organizations sponsoring the alliance were prominent high-technology firms (NEC, Sony, DEC, Daewoo, AT\&T, and Silicon Graphics) and issues with the translation of technology among them contributed to the dissolution of the alliance mode. The network was organized via strategic collaborative agreement, to which all network members were party, but had no joint organization overseeing alliance management. Problems arose precisely because of the lack of control in the lateral configuration of the alliance mode and MIPS was bought out in 1992 by Silicon Graphics. Dissolution of the alliance did not mean death of the new organization (i.e., RISC). The buy-out in this case is similar to the logic of absorbing projects, suggesting that alliance forms may need higher levels of formalization and control to produce desired organizational effects.

Gulati et. al. (2000) have argued that an additional challenge in studying organizational novelty in alliance modalities is the "private and invisible" (2000, p. 12) flow of knowledge. Attempts to reveal what is going on inside the ties tend to obscure these processes further by developing measures that may be peripheral to the mechanisms via which knowledge flows. Anand and Khanna (2000) argue that value creation in alliances is gauged by the dollar performance of unanticipated excess returns by the parties in the period following alliance formation. They operationalize 'value creation' as the firm's 'experience' in managing alliances and the unobserved heterogeneity between firms on this proxy. Alliance experience is the 'number of alliances' to which a firm has been part. The authors found correlation between number of alliances and excess returns, as it is logical to expect that in transactional arrangements involving equity, additional returns are reaped at the time of alliance formation. Nonetheless, the authors conclude that theirs "is one of the first studies to establish systematic evidence for the existence of learning effects in the management of alliances"(ibid, p. 313). 
Dyer and Nobeoka's (2000) study of Toyota is another example tracing processes related to the emergence of learning effects in organizations. Their analysis indicates that because Toyota's suppliers "do learn more quickly after participating in Toyota's knowledge-sharing network" (2000, p. 345), Toyota had created an organizational identity of the organic type. The design of relationships is such that the firm maintains a set of coordinating rules fostering the emergence of collective routines by which tacit knowledge is shared. Toyota uses three organizational vehicles that facilitate knowledge transfer. The supplier association is a network-level forum that functions through topic committees that facilitate knowledge sharing on topics that are highly consequential to commercial and non-commercial performance. These topics (e.g., 'eliminating supplier design defects') cultivate the building of common identity among members. Problem solving teams solve emergent know-how problems in supplier organizations. Finally, flexible 3-year voluntary learning teams foster the emergence of some form of collective solidarity between the participants who learn to "identify" with a larger collective" (ibid, p. 503). This type of interpenetration of practices throughout an organization indicates that large firms can be organized for the organization of new knowledge and evolve as organic wholes.

Network literature hypothesizes that if simple network forms, such as licensing can be associated with learning, then the very "nature" of collaboration in networks differs substantially from the bureaucratic logic of Chandlerian enterprise. Powell et. al. (1996) explain that by controlling for prior levels of connectedness, learning happens when actors become more central and the future portfolio of ties of focal firms becomes more diverse. Podolny and Page (1998) have however suggested that network methodology should clarify how firms learn by collaboration. Otherwise, transaction costs enthusiasts can explain the positive effects of networks by good management of resource dependencies that enhances the legitimacy of participating firms.

\section{Discussion and Future Research}

This review has examined recent research on post-Weberian organization attempting to discover particular components of novelty that exhibit ideal-typical features. The paper reports that while the distinctive features of Weber's bureaucratic type have remained unaffected, trends in contemporary organizing have warranted to propose that there is a convergence in the type of motivation for change. The organizations of the future may be flexible learners that quickly build the competences that "match the type of change that they face" (Afuah, 2001, p. 1225). However, as noted throughout this paper, future submissions should be cautious of recording extreme diversity in conceptualizing post-bureaucratic novelty in organizational forms. As noted by Hecksher, an ideal-typical post-bureaucratic organization as of yet, "doesn't exist" (Hecksher, 1994, p. 17). Caution is also prescribed by Romanelli (1991) in population ecology that defining numerous variants of new forms can be precarious to any one's propensity to survive, because the continual introduction of new organizational forms in a domain can produce feeble offspring.

This paper derives three conditions for post-bureaucratic novelty depending on the variations in two types of motivations for change, knowledge transfer and learning, for each of the two types of organizational transformation outlined in this paper (Figure 1). In post-Weberian trajectories of transformation, organizational change is grounded in the intentionality to learn. In mutating multinational organizations, management intentionality for change is frequently based on the intention to capture and transfer knowledge.

The first condition is that future research categorizes the exact type of change through which the multidivisional enterprise is mutating. This paper shows that motivations for restructuring in large organizations are related primarily to knowledge transfer. While these organizations do experiment with new practices, they are likely to cofound them along old organizational structures and routines (see, Stark, 1989). For instance, we observed that the launch of new interdivisional units in which individuals work on projects with different degrees of inter-functionality does not solve the agency problem between functional and project lines and is a mutation practice. The fact that organizational change hinges on knowledge transfer is well documented when project forms are drafted by large firms to gain knowledge on complex and potentially repetitive transactions and transfer the acquired knowledge by absorbing the project back into the formal structure. 


\section{Post-Weberian forms/ change motivated by learning}

\author{
M-form mutations/ \\ change motivated by \\ knowledge transfer
}

\begin{tabular}{|} 
Project-based forms (PBFs) \\
"Precarious" Projects \\
(Whitley, 2006) \\
Project Networks (Carruthers \\
and Uzzi, 2000; Windeler and \\
Sydow, 2001)
\end{tabular}

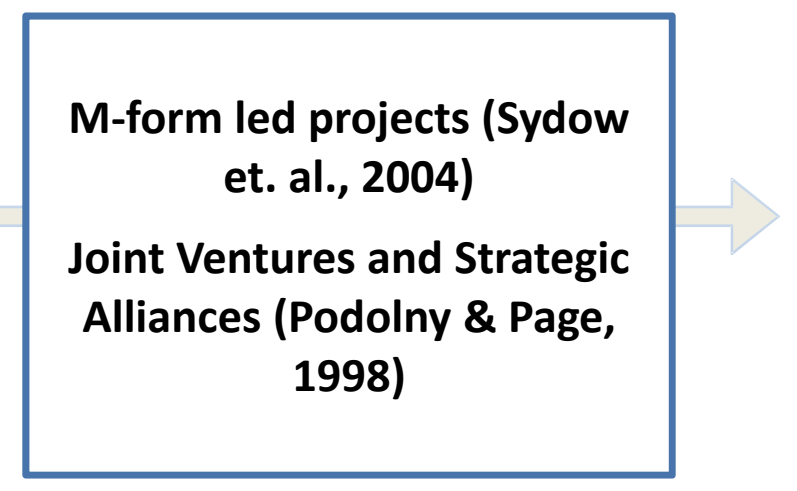

Figure 1. Managerial Intentionality and Post-Bureaucratic Organization

Cases of lateral disintegration in large firms can be related to post-bureaucratic change, if the addition of a lateral unit shows patterns of transformations in which "new unities with larger competencies" (Selznik \& Nonet, 1978, p. 23) supplant functional arrangements previously built in a hierarchical "supporting relation to one another" (Williamson, 1991, p. 271). Dyer and Nobeoka's (2000) case study of Toyota shows that when restructuring is continually aligned with management intentionality motivated by learning, the result is an organization that enhances the existing competences and motivations of other peers at the level of the organizational community. As a result, the second condition calls to position patterns of transformation in contemporary organizations outside Weberian and Williamsonian continuums. New patterns of transforming in organizations should be associated with different intentionality from the one observed in bureaucratic organization. Post-bureaucratic transformations should also separate from transaction costs economizing logic of organizing (Figure 1). Project-led forms are frequently associated with high degrees of formalization. Formalization in projects led by multidivisional organizations is intended for codifying and absorbing project results back into the routines of the organization at the stage when the project is folded back into the functional structure.

The third condition for post-bureaucratic novelty is that patterns of transformations based on the intent to learn may not always result in the most "adaptive" form. Emerging patterns of post-bureaucratic transformation may include organizations that disband or otherwise cease to exist because of the intentional investment of managers in learning and experimenting with contextual knowledge. This interorganizational arrangement has recently surfaced in online communities of practice (Shah \& Tripsas, 2007). In this paper, pure "precarious" project-based forms (PBFs) as described by Whitley (2006) are frequently impermanent organizational entities. With the advent of forms of business motivated by learning, organizations are less likely to fail due to inherently faulty design. Rather, the motivation to learn can be precarious, when we revisit Volberda's (1996) and Toffler's (1970) assumptions of instability inherent in the adhocracy and chaotic forms.

\section{Acknowledgement}

Special thanks to David Stark, Josh Whitford, and Bruce Kogut on their help with earlier drafts of this paper at the Center for Organizational Innovation (COI) at Columbia University, and the editor and anonymous reviewer for their helpful comments. 


\section{References}

Achrol, R. S. (1997). Changes in the theory of interorganizational relations in marketing, toward a network paradigm. Journal of the academy of marketing science, 25(1), 56-71. http://dx.doi.org/10.1007/BF02894509

Afuah, A. (2001). Dynamic boundaries of the firm: Are firms better off being vertically integrated in the face of a technological change? Academy of Management Journal, 44(6), 1211-1228. http://dx.doi.org/10.2307/3069397

Aldrich, H., \& Ruef, M. (2006). Organizations Evolving. Thousand Oaks CA: Sage Publications.

Anand, B., \& Khanna, T. (2000). Do firms learn to create value? The case of alliances. Strategic Management $\begin{array}{llr}\text { Journal, } & 21(3), & 295-315 .\end{array}$ http://dx.doi.org/10.1002/(SICI)1097-0266(200003)21:3<295::AID-SMJ91>3.0.CO;2-O

Andrews, K. (1971). The Concept of Corporate Strategy. Irwin, Homewood, IL.

Ulrich, D., Jick, T., Kerr, S., Prahalad, C. K., \& Bossidy, L. A. (2002). The boundaryless organization: Breaking the chains of organizational structure (pp. 72-75). San Francisco: Jossey-Bass.

Bartlett, C. A., \& Ghoshal, S. (2002). Managing across borders: The transnational solution (2nd ed.). Harvard Business School Press, Boston, MA.

Bell, D. (1976). The coming of post-industrial society. Basic Books, New York.

Birkinshaw, J. M., \& Hagström, P. (eds.) (2000). The flexible firm: capability management in network organizations. Oxford University Press.

Boisot, Max H., \& Child, J. (1988). The iron law of fiefs: Bureaucratic failure \& the problem of governance in the Chinese economic reforms. Admin Sci. Quart, 33, 507-527. http://dx.doi.org/10.2307/2392641

Brady, T., \& Davies, R. (2004). Building project capabilities: from exploratory to exploitative learning. Organization studies, 25(9), 1601-1621. http://dx.doi.org/10.1177/0170840604048002

Brown, J.L., Cooper, D.J., Greenwood, R., \& Hinings, C.R. (1996). Strategic alliances within a big-six accounting firm. International Studies of Management \& Organization, 26(2), 59-79.

Brynjolfsson, E., Renshaw, A., \& Van Alstyne, M. (1997). The matrix of change. Sloan Management Review, 38(2), $37-54$.

Burns, T., \& Stalker, G. M. (1961). The management of innovation. Tavistock, London.

Carroll G. R., \& Hannan, M. T. (2000). The demography of corporations \& industries. Princeton University Press: Princeton, NJ.

Carruthers, B., \& Uzzi. B. (2000). Economic sociology \& organization theory in the new millennium. Contemporary Sociology, 29(3), 486-494. http://dx.doi.org/10.2307/2653936

Castells, M. (2011). The rise of the network society: The information age: Economy, society, and culture (Vol. 1). John Wiley \& Sons.

Chandler, A.D., Jr. (1962). Strategy and structure. Doubleday, Anchor Books Edition, New York.

Chiesa V., Manzini R., \& Pizzurno E. (2004). The externalization of R\&D activities \& the growing market of product development $\quad$ services. $\quad R \& D \quad$ Management $\quad$ (UK), $\quad 34(1), \quad 65-76$. http://dx.doi.org/10.1111/j.1467-9310.2004.00323.x

Child, J., \& McGrath, R.G. (2001). Organizations unfettered: organizational form in an information-intensive economy. Academy of Management Journal, 44(6), 1135-1148. http://dx.doi.org/10.2307/3069393

Child, J., \& Rodrigues, S. B. (2003). Corporate governance \& new organization forms: issues of double \& multiple agency. Journal of Management \& Governance, 7(4), 337-360. http://dx.doi.org/10.1023/A:1026210608769

Clegg, S., Hardy, S., \& Nord, W. (1996). Handbook of Organization Studies(Eds.). Thousand Oaks, CA: Sage.

Cravens, D. W., Piercy, N. F., \& Shipp, S. H. (2006). New organizational forms for competing in highly dynamic environments: the network paradigm. British Journal of Management, 7(3), 203-218. http://dx.doi.org/10.1111/j.1467-8551.1996.tb00115.x

Cross, R. L., Yan, A., \& Louis, M. R. (2000). Boundary activities in "boundaryless" organizations: A case study of a transformation to a team-based structure. Human Relations, 53, 841-868. http://dx.doi.org/10.1177/0018726700536004 
Cyert, R. M., \& March, J. G. (1963). A behavioral theory of the firm. Prentice-Hall, Englewood Cliffs, NJ.

Daft, R., \& Lewin, A. (1993). Where are the theories of the 'new' organizational forms? Organization Science, 4, i-iv.

Davidow, W.H., \& Malone, M.S. (1992). The virtual corporation - structuring \& revitalizing the corporation for the 21 st century. New York: HarperCollins.

Davis, G. F., \& Marquis, C. (2005). Prospects for theory about organizations in the early 21st century: Institutional field \& mechanisms. Organization Science, 6(4), 332-343. http://dx.doi.org/10.1287/orsc.1050.0137

Day, J. D., \& Wendler, J. C. (2000). Success by Design Senior executives play the role of architects of structure and systems. Executive Excellence, 17(7), 6-7.

DeFillippi, R., \& Arthur, M. (1998). Paradox in project-based enterprise: The case of filmmaking. California Management Review, 40(2), 125-139. http://dx.doi.org/10.2307/41165936

Dess, G. G., Rasheed, M. A., McLaughlin, K. J., \& Priem, R. L. (1995). The new corporate architecture. Academy of Management Executive, 9(3), 7-18.

Dijksterhuis, M. S., Van den Bosch, F. A., \& Volberda, H. W. (1999). Where do new organizational forms come from? Management logics as a source of coevolution. Organization Science, 10(5), 569-582. http://dx.doi.org/10.1287/orsc.10.5.569

DiMaggio, P. J., \& Powell, W. W. (1983). The iron cage revisited: institutional isomorphism \& collective rationality in organizational fields. American Sociological Review, 48, 147-60. http://dx.doi.org/10.2307/2095101

Drucker: F. (1993). Post-capitalist society. HarperCollins, New York.

Dunford, R., Palmer, I.C., Benveniste, J., \& Crawford, J.D. (2007). Coexistence of 'old' \& 'new' organizational practices: Transitory phenomenon or enduring feature? Asia Pacific Journal of Human Resources, 45(1), 24-43. http://dx.doi.org/10.1177/1038411107073597

Dunning, J. H. (1995). Reappraising the eclectic paradigm in an age of alliance capitalism. Journal of International Business Studies, 26(3), 461-491. http://dx.doi.org/10.1057/palgrave.jibs.8490183

Dyer, J. H., \& Nobeoka, K. (2000). Creating \& managing a high-performance knowledge-sharing network: the Toyota case. Strategic Management Journal, 21(3), 345-367. http://dx.doi.org/10.1002/(SICI)1097-0266(200003)21:3<345::AID-SMJ96>3.0.CO;2-N

Dyer, Jeffrey H. (1996). Specialized supplier networks as a source of competitive advantage: evidence from the auto $\begin{array}{llll}\text { industry. } & \text { Strategic } & \text { Management }\end{array}$ http://dx.doi.org/10.1002/(SICI)1097-0266(199604)17:4<271::AID-SMJ807>3.0.CO;2-Y

Engardio, P., Arndt, M., \& Foust, D. (2006). The future of outsourcing. Business Week, 30, 50-64.

Engwall, M., \& Westling, G. (2004). Peripety in an R\&D Drama: capturing a turnaround in project dynamics. Organization Studies, 25(9), 1557-1578. http://dx.doi.org/10.1177/0170840604048000

Feenstra, R. (1998). Integration of trade and disintegration of production in the global economy. Journal of Economic Perspectives, 12(4), 31-50. http://dx.doi.org/10.1257/jep.12.4.31

Fiol, C. M., \& Romanelli, E. (2012). Before identity: the emergence of new organizational forms. Organization Science, 23(3), 597-611. http://dx.doi.org/10.1287/orsc.1110.0666

Fulk J., \& DeSanctis G. (1995). Electronic communication \& changing organizational forms. Organization Science, 6(4), 337-49. http://dx.doi.org/10.1287/orsc.6.4.337

Galunic, D. C., \& Eisenhardt, K. M. (1996). The evolution of intracorporate domains: Divisional charter losses in high-technology, multidivisional corporations. Organization Science, 7(3), 255-282. http://dx.doi.org/10.1287/orsc.7.3.255

Gordon, J. (1992). Work teams: How far have they come? Training-New York Then Minneapolis, 29, 59.

Grabher, G. (2004). Temporary architectures of learning: knowledge governance in project ecologies. Organization Studies, 25, 1491-1514. http://dx.doi.org/10.1177/0170840604047996

Gulati, R. (1998). Network location \& learning: The influence of network resources \& firm capabilities on alliance formation. Strategic Management http://dx.doi.org/10.1002/(SICI)1097-0266(199905)20:5<397::AID-SMJ35>3.0.CO;2-K 
Gulati, R., Nohria, N., \& Zaheer, A. (2000). Strategic Networks. Strategic Management Journal, 21(3), 203. http://dx.doi.org/10.1002/(SICI)1097-0266(200003)21:3<203::AID-SMJ102>3.0.CO;2-K

Hagedoorn, J. (1995). Strategic technology partnering during the 1980s: Trends, networks, \& corporate patterns in non-core technologies. Research Policy, 24, 207-231. http://dx.doi.org/10.1016/0048-7333(94)00763-W

Hagel, J. (2002). Web services \& the development of value chains: insights from John Hagel. Internet World, December 4, 2002.

Hannan, M. T., \& Freeman, J. (1986, December). Where do organizational forms come from? In Sociological forum (Vol. 1, No. 1, pp. 50-72). Kluwer Academic Publishers. http://dx.doi.org/10.1007/BF01115073

Hannan, M. T. (2005). Ecologies of organizations: diversity \& identity. Journal of Economic Perspectives, 19(1), 51-70. http://dx.doi.org/10.1257/0895330053147985

Heckscher, C. (1994). Defining the post-bureaucratic type. In C. Heckscher \& A. Donnellon (Eds.), The Post-Bureaucratic Organization: New Perspectives on Organizational Change, Thousand Oaks, CA: Sage, pp. 14-62.

Hedlund, G. (1994). A model of knowledge management and the N-form corporation. Strategic management journal, 15(S2), 73-90. http://dx.doi.org/10.1002/smj.4250151006

Helper, S. (1990). Comparative supplier relations in the US and Japanese auto industries: an exit/voice approach. Business and Economic History, 153-162.

Heydebrand, W. (1989). New organizational forms. Work \& Occupations, 16, 323-357. http://dx.doi.org/10.1177/0730888489016003004

Hirschhorn, L., \& Gilmore, T. (1992). The new boundaries of the 'boundaryless' company. Harvard Business Review, 70(3), 104-115.

Hobday, M. (2000). The project-based organisation: An ideal form for managing complex products \& systems? Research Policy, 29, 871-893. http://dx.doi.org/10.1016/S0048-7333(00)00110-4

Hsu, G., \& Hannan, M. T. (2005). Identities, genres, \& organizational forms. Organization Science, 16(5), 474-90. http://dx.doi.org/10.1287/orsc.1050.0151

Ilinitch, A., R. D'Aveni, \& Lewin, A. (1996). New organizational forms \& strategies for managing in hypercompetitive environments. Organization Science, 7(3), 211-220. http://dx.doi.org/10.1287/orsc.7.3.211

Joyce, W.F., McGee, V.E., \& Slocum, J.W. (1997). Designing lateral organizations: an analysis of the benefits, costs, $\&$ enablers of nonhierarchical organizational forms. Decision Sciences, 28(1), 25. http://dx.doi.org/10.1111/j.1540-5915.1997.tb01300.x

Kogut, B., \& Zander, U. (1992). Knowledge of the firm, combinative capabilities, \& the replication of technology. Organization Science, 3, 383-397. http://dx.doi.org/10.1287/orsc.3.3.383

Koza, M. P., \& Lewin. A. Y. (1998). The co-evolution of strategic alliances. Organ. Sci., 9(3), 255-264. http://dx.doi.org/10.1287/orsc.9.3.255

Lei, D., Hitt, M.A., \& Bettis, R. (1996). Dynamic core competences through meta-learning \& strategic context. Journal of Management, 22(4), 549-569. http://dx.doi.org/10.1177/014920639602200402

Lewin, A. Y., \& Volberda, H. W. (1999). Prolegomena on coevolution: A framework for research on strategy and new organizational forms. Organization science, 10(5), 519-534. http://dx.doi.org/10.1287/orsc.10.5.519

Lieberman, M., \& Asaba, S. (1997). Inventory reduction \& productivity growth: A comparison of Japanese \& U. S. automotive sectors. Managerial and Decision Economics, 18(2), 73-85.

Lindkvist, L. (2004). Governing project-based firms: Promoting market-like processes within hierarchies. Journal of Management \& Governance, 8, 3-25. http://dx.doi.org/10.1023/B:MAGO.0000015392.75507.ad

Malnight, T. (2001). Emerging structural patterns within multinational corporations: Toward process-based structure. Academy of Management Journal, 44(6), 1187-1210. http://dx.doi.org/10.2307/3069396

March, J. G. (1995). The future, disposable organizations \& the rigidities of imagination. Organization, 2(3/4), 427-440. http://dx.doi.org/10.1177/135050849523009

Mckendrick, D. G., Jaffee, J., Carroll, G., \& Khessina, O. (2003). In the Bud? Disk array producers as a (possibly) emergent organizational form. Administrative Science Quarterly, 48(1), 60-93. 
http://dx.doi.org/10.2307/3556619

Mehta, S. (1994). Enterprise: Cell manufacturing gains acceptance at smaller plants. Wall Street Journal, September $15, \mathrm{~B} 2$.

Miles, R. E., \& Snow, C. C. (1986). Organizations: new concepts for new forms. California Management Review, 28(3), 62-73. http://dx.doi.org/10.2307/41165202

Miles, R.E., \& Snow, C.C. (1995). The new network firm: a spherical structure based on a human investment philosophy. Organizational Dynamics, 23, 5-18. http://dx.doi.org/10.1016/0090-2616(95)90013-6

Mintzberg, H. (1983). Structure in fives: designing effective organizations. Englewood Cliffs, N.J.: Prentice-Hall, c1983.

Nelson, R. R., \& Winter, S. G. (1982). An evolutionary theory of economic change. Cambridge, Mass: Harvard Univ. Press.

Nohria, N., \& G. Eccles (1992). Networks \& organizations: structure, form \& action. Harvard Business School Press, Boston, MA.

Ouchi, W. G. (1980). Markets, bureaucracies, and clans. Administrative science quarterly, 25(1). http://dx.doi.org/10.2307/2392231

Ouchi, W. G., \& Jaeger. A. M. (1978). Type Z organization: Stability in the midst of mobility. Academy of Management Review, 3, 305-314.

Palmer, I.C., Benveniste, J., \& Dunford, R. (2007). New organizational forms: Towards a generative dialogue. Organization Studies, 28(12), 1829-1847. http://dx.doi.org/10.1177/0170840607079531

Perrow C. (2001). An organizational analysis of organizational theory. Contemporary Sociology, 29, 469-476. http://dx.doi.org/10.2307/2653934

Pfeffer, J., \& Nowak, P. (1976). Joint venture \& interorganizational interdependence. Administrative Science Quarterly, 21(3), 398-418. http://dx.doi.org/10.2307/2391851

Podolny, J. M., \& Page, K. L. (1998). Network forms of organization. Annual review of sociology, 57-76. http://dx.doi.org/10.1146/annurev.soc.24.1.57

Powell, W. (2003). Neither market nor hierarchy. The sociology of organizations: classic, contemporary, and critical readings, $315,104-117$.

Powell, W. W. (2001). The capitalist firm in the twenty-first century: Emerging patterns in western enterprise. In P. DiMaggio (ed.), The Twenty-First Century Firm: Changing Economic Organization in International Perspective. Princeton University Press, Princeton, NJ.

Powell, W., Kenneth W. Koput, \& Smith-Doerr, L. (1996). Interorganizational collaboration \& the locus of innovation: networks of learning in biotechnology. Administrative Science Quarterly, 41, 1996.

Puranam, P., Alexy, O., \& Reitzig, M. (2014). What's 'new' about new forms of organizing? Academy of Management Review, 39(2), 162-180. http://dx.doi.org/10.5465/amr.2011.0436

Quinn, J. B. (1992). The intelligent enterprise a new paradigm. Acad. Management Executive, 6(4) 48-63.

Rindova, V., \& Kotha, S. (2001). Continuous morphing: Competing through dynamic capabilities, form, \& function. Academy of Management Journal, 44(6), 1263-1280. http://dx.doi.org/10.2307/3069400

Romanelli, Elaine (1991). The evolution of new organizational forms. Annual Review of Sociology, 17, 79-103. http://dx.doi.org/10.1146/annurev.so.17.080191.000455

Saxenian, A. (1994). Regional advantage: culture \& competition in Silicon Valley \& route 128. Cambridge, MA: Harvard University Press, 1994.

Schilling, M.A., \& Steensma, K. (2001). The use of modular organizational forms: An industry level analysis. Academy of Management Journal, 44, 1149-1169. http://dx.doi.org/10.2307/3069394

Schotter, A. (2008). The economic theory of social institutions. Cambridge Books.

Scott, W. R. (2004). Reflections on a half-century of organizational sociology. Annual Rev. Sociol., 30, 1-21. http://dx.doi.org/10.1146/annurev.soc.30.012703.110644

Selznick, P., \& Nonet, P. (1978). Law and society in transition: toward responsive law. Law and Society in transition: 
toward responsive law. New York: Harper Colophon Books.

Shah, S. K., \& Tripsas, M. (2007). The accidental entrepreneur: The emergent and collective process of user entrepreneurship. Strategic Entrepreneurship Journal, 1(1-2), 123-140. http://dx.doi.org/10.1002/sej.15

Smith, A. D., \& Zeithaml, C. (1996). Garbage cans and advancing hypercompetition: the creation and exploitation of new capabilities and strategic flexibility in two regional Bell operating companies. Organization Science, 7(4), 388-399. http://dx.doi.org/10.1287/orsc.7.4.388

Stark, D. (1989). Co-existing organizational forms in Hungary's emerging mixed economy. In Victor Nee \& David Stark (eds.), Remaking the Economic Institutions of Socialism; China \& Eastern Europe. Stanford: Stanford University Press, 1989. pp. 137-168.

Stinchcombe, A. L. (1965). Organizations and social structure. In J. G. March, ed. Handbook of Organizations. R\& McNally, Chicago. 142-193.

Stuart, T.E., Hoang, H., \& Hybels, R. (1999). Interorganizational endorsements \& the performance of entrepreneurial ventures. Administrative Science Quarterly, 44, 315-349. http://dx.doi.org/10.2307/2666998

Stuart, Toby E. (1998). Producer network positions \& propensities to collaborate: an investigation of strategic alliance formations in a high-technology industry. Administrative Science Quarterly, 43(3), 668-698. http://dx.doi.org/10.2307/2393679

Sydow, J., Lindkvist, L., \& DeFillippi, R. (2004). Project-based organizations, embeddedness \& repositories of knowledge: Editorial. Organization Studies, 25(9), 1475-1489. http://dx.doi.org/10.1177/0170840604048162

Teece, D., Pisano, G., \& Shuen, A. (1997). Dynamic capabilities \& strategic management. Strategic Management Journal, 18, 509-533. http://dx.doi.org/10.1002/(SICI)1097-0266(199708)18:7<509::AID-SMJ882>3.0.CO;2-Z

Toffler, A. (1970). Future Shock. New York: Random House.

Tushman, M., \& O'Reilly, C.A. (2006). Ambidextrous organizations- managing evolutionary \& revolutionary change. In David Mayle(ed.), Managing Innovation \& Change, pp. 170-184. SAGE.

Uzzi, B., \& Spiro, J. (2005). Collaboration and creativity: the small world problem. American journal of sociology, 111(2), 447-504. http://dx.doi.org/10.1086/432782

Uzzi, B. (1997). The sources \& consequences of embeddedness for the economic performance of organizations: the network effect. American Sociological Review, 61(4), 674-698. http://dx.doi.org/10.2307/2096399

Verespej, M. A. (1990). When you put the team in charge. Industry Week, December 3, 30-31.

Volberda, H. W. (1996). Toward the flexible form: How to remain vital in hypercompetitive environments. Organ. Sci., 7(4), 359-374. http://dx.doi.org/10.1287/orsc.7.4.359

Walsh, J. P., Meyer, A. D., \& Schoonhoven, C. B. (2006). A future for organization theory: Living in and living with changing organizations. Organization Science, 17(5), 657-671. http://dx.doi.org/10.1287/orsc.1060.0215

Weber, Max (1968). Economy and society. Edited by Guenther Roth \& Claus Wittich. New York: Bedminister Press, 1968, vol. 1.

Weick, K. E. (1977). Organization design: Organizations as self-designing systems. Organizational dynamics, 6(2), 31-46. http://dx.doi.org/10.1016/0090-2616(77)90044-4

Whitley, R. (2006). Project-based firms: new organizational form or variations on a theme? Industrial and corporate change, 15(1), 77-99.

Williamson, O. E. (1991). Comparative economic organization: The analysis of discrete structural alternatives. Admin. Sci. Quart., 36(2), 269-296. http://dx.doi.org/10.2307/2393356

Windeler, A., \& Sydow, J. (2001). Project networks \& changing industry practices - Collaborative content production in the German television industry. Organization Studies, 22(6), 1035-1061. http://dx.doi.org/10.1177/0170840601226006

Wry, T., Lounsbury, M., \& Glynn, M. A. (2011). Legitimating nascent collective identities: Coordinating cultural entrepreneurship. Organization Science, 22(2), 449-463. http://dx.doi.org/10.1287/orsc.1100.0613

Zenger, T.R., \& Hesterly, W.S. (1997). The disaggregation of corporations: selective intervention high-powered incentives \& molecular units. Organization Science, 8, 209-222. http://dx.doi.org/10.1287/orsc.8.3.209 


\section{Notes}

Note 1. For example, Dess et. al. (1995) argue that Apple is simultaneously modular, virtual, and boundaryless, because the firm pursues strategic alliances with rivals such as Motorola and IBM; outsourced its Newton platform from Sharp; and provides access for partners an suppliers to its internal e-system.

Note 2. These results are obtained when performance is measured as technical performance ("SPECinteger"), a calculation in which the unit of performance is speed alone.

Note 3. It is of note that due to the high risks associated with this business, large pharmaceutical firms may be impervious to opening their processes and structures in particular ways to the environment, and it is unclear what management logics are employed internally. The linkages that these firms utilize with small biotech companies, however, are arguably novel. 